\title{
Addressing Information Asymmetries in Online Peer-to-Peer Lending
}

\author{
Mark Cummins, Theo Lynn, Ciarán Mac an Bhaird \\ and Pierangelo Rosati
}

Abstract Digital technologies are transforming how small businesses access finance and from whom. This chapter explores online peer-to-peer (P2P) lending, a form of crowdfunding that connects borrowers and lenders. Information asymmetry is a key issue in online peer-to-peer lending marketplaces that can result in moral hazard or adverse selection, and ultimately impact the viability and success of individual platforms.

The authors are listed in alphabetical order.

M. Cummins · T. Lynn $(\bowtie) \cdot$ P. Rosati

DCU Business School, Dublin City University, Dublin, Ireland

e-mail: theo.lynn@dcu.ie

M. Cummins

e-mail: mark.cummins@dcu.ie

P. Rosati

e-mail: pierangelo.rosati@dcu.ie

C. Mac an Bhaird

Dublin City University, Dublin, Ireland

e-mail: ciaran.macanbhaird@dcu.ie

(C) The Author(s) 2019

T. Lynn et al. (eds.), Disrupting Finance, Palgrave Studies

in Digital Business \& Enabling Technologies,

https://doi.org/10.1007/978-3-030-02330-0_2 
Both online P2P lending platforms and lenders seek to minimise the impact of information asymmetries through a variety of mechanisms. This chapter discusses the structure of online P2P lending platforms and reviews how the disclosure of hard and soft information, and herding can reduce information asymmetries. The chapter concludes with a discussion of further avenues for research.

Keywords P2P lending - Online P2P lending - Information asymmetry

\subsection{INTRODUCTION}

It is widely agreed that small businesses play a critical role in economic growth, regardless of country size or development, by providing employment and income to a broad range of citizens, supporting a wider eco-system of firms, and fostering innovation (OECD 2017a). Their viability, sustainability, and growth depend on access to strategic resources, not least finance. The supply and sourcing of financing is a perennial strategic challenge for small businesses the world over, exacerbated by their innate characteristics and market inefficiencies. Due to undercollateralisation, limited or no credit history, and lack of sophisticated financial statements (and the expertise to produce such statements), a higher level of default risk is typically attached to small businesses and as a result access to credit is limited (Bhide 2003; OECD 2013). This situation persists despite a consistent decrease in the costs of financing in recent years, partly as result of the aforementioned characteristics of small business but also as a result of supply-side lending policies by traditional credit sources during the recent recession (Mills and McCarthy 2014; OECD 2017b).

Digital technologies are transforming the business models and dramatically increasing access to markets for small businesses. In the same way, it is also transforming how these businesses access finance and from whom. This chapter explores online peer-to-peer (P2P) lending, a form of crowdfunding (see Chapter 1 ) that bypasses conventional intermediaries, processes, and requirements to connect borrowers and lenders (Yum et al. 2012). Information asymmetry is a key issue in P2P lending that can result in moral hazard or adverse selection (Akerlof 1970) and ultimately impact the viability and success of individual P2P lending platforms. Both $\mathrm{P} 2 \mathrm{P}$ lending platforms and lenders seek to minimise the impact of information asymmetries through a variety of mechanisms, 
most notably by supplementing hard information with soft information, and herding. The remainder of this chapter discusses the structure of online P2P lending platforms in greater detail. Extant literature on information asymmetries and online peer-to-peer lending platforms is then discussed. The chapter concludes with a discussion of further avenues for research.

\subsection{Online Peer-to-Peer Lending Platforms}

Online P2P lending platforms represent a convergence of P2P lending and collective financing, enabled by an Internet-based platform. Both P2P lending and collective financing are not new ideas in themselves. New venture financing, in particular, often mobilises existing peers based on family, friendship, or professional social relationships with the entrepreneur(s) (Berger and Udell 1998; Kotha and George 2012; Robb and Robinson 2014). This type of funding is often referred to as insider or informal funding in contrast to formal finance, whether intermediated from an equity or debt perspective (Berger and Udell 1998). Similarly, collective financing has a long history. Haas et al. (2014) cite the funding of the Statue of Liberty's pedestal in the nineteenth century as an early example of collective financing. In contrast, online P2P lending platforms harness the power of the Internet to enable an online marketplace for microcredit funding that acts as an intermediary to connect individuals or businesses wishing to obtain a loan (borrowers) with individuals and institutions wishing to fund loans (lenders). Lenders may not necessarily have existing social relationships with the entrepreneurs, management, or the business, and are more likely strangers with no preexisting relationship. They may be individuals or organisations established to provide credit on a formal basis. As such, online P2P lending platforms may, and increasingly do, allow traditional credit institutions such as banks to invest.

Online P2P lending marketplaces are two-sided networks where a P2P lending platform enables interactions between the demand (the borrower) and supply (the lender) sides of the network. ${ }^{1}$ As well as recruiting potential borrowers and lenders (market-making), the P2P lending platform sets the rules or terms of engagement between borrowers and lenders in the platform. Typically, registered borrowers post

\footnotetext{
${ }^{1}$ For the remainder of this chapter, 'P2P lending' refers to online $\mathrm{P} 2 \mathrm{P}$ lending.
} 
their funding requirements on the platform and provide a relatively limited amount of information for due diligence purposes. The amount of information potential borrowers are required to submit varies among different platforms. For individuals, this might include detail on income, employment, other debt, purpose of loan, and a personal statement; for businesses, this typically includes financial accounts, some form of statement of historic trading, along with details of the lending proposition. In some marketplaces, additional information or verification can be requested (see later discussion on groups). The P2P lending platform then makes a decision to list the loan request or not. The P2P lending platform collects and scores prospective borrowers individually or as a pool, typically using a proprietary credit scoring mechanism. The potential loan requests are then offered to the prospective lenders through the platform. The prospective lenders then can decide to make offers (bids) to meet the full or partial loan requirements at a specific interest rate, if any. ${ }^{2}$ Depending on the platform's functionality, such bids can be made by the prospective lenders manually (and independently), in groups, or using automated rule-based tools for portfolio management offered by the platform. By allowing lenders to invest in multiple small loans or small parts of a loan, the platform offers them the opportunity to diversify their loan portfolio and associated risk. The loan is funded when the minimum loan requirements are met, i.e. loan amount and interest rate. Finally, once the loan has been granted, the platform facilitates the loan processing and repayments and continues to collect and analyse the data relating to the loan and borrower for use in future credit scoring. P2P platforms mainly generate income from (1) origination fees from the borrower deducted at loan disbursement, (2) repayment fees charged to the lender when the borrower pays a monthly statement, and (3) additional charges such as late fees, loan part trading fees etc.

While the P2P lending platform undertakes a variety of functions including market-making, loan processing, and community-building activities, they do not, as a rule, participate in lending decisions (Meyer 2007; Wang et al. 2009). ${ }^{3}$ As they do not make lending decisions

\footnotetext{
${ }^{2}$ In some social lending platforms, the interest rate can be zero e.g. kiva.org.

${ }^{3} \mathrm{~A}$ variant of online peer-to-peer lending platforms, balance sheet business lending and balance sheet property lending, has emerged in recent years and involves the platform entity providing loans directly to businesses. It accounts for a very small proportion of the sector. This has been excluded from this chapter as there is typically no market for the loans per se and the platform and lender are one and the same.
} 
(or collect deposits as in traditional banks), they have much lower transaction and intermediation costs than conventional credit institutions-key drivers of interest margins (Maudos and Guevara 2004). Operating costs are minimised through the use of online automated systems, operating outside the banking regulatory system, and not carrying the loans on their books thus avoiding liabilities for loans (Serrano-Cinca et al. 2015). These lower costs are transferred across to both the supply and demand sides of the P2P network. Accordingly, borrowers are attracted to P2P lending platforms by transparency, rapid decision-making, the promise of non-collateralised loans often at competitive interest rates (Sviokla 2009; Wang et al. 2009; IOSCO 2017) and lenders are attracted by lower transaction costs, risk diversification, access to market, and higher potential returns (Morse 2015; IOSCO 2017).

Given the strong incentives for all stakeholders in the P2P lending value network, it is unsurprising that the $\mathrm{P} 2 \mathrm{P}$ lending segment has experienced rapid and substantial growth since the launch of what is considered the first online P2P lending platform, Zopa.com, in 2005. P2P lending platforms may be categorised in a variety of ways including business model (profit/not-for-profit), number of borrowers per loan (oneto-one/one-to-many), borrower type (consumer/business) or loan use (e.g. real estate financing). P2P lending is still at a relatively early stage of development and analyst reports on market sizing is characterised by regional focus, definitional ambiguity, and significant variances. Table 2.1 provides a summary of the size of the overall market and main segments by region.

The rapid growth of P2P lending has been justified through two main arguments-financial intermediation theory and market equilibrium theory (Serrano-Cinca et al. 2015). The financial intermediation hypothesis suggests that as P2P lending platforms are more cost efficient than traditional credit institutions and therefore have lower intermediation costs, they are more attractive to both lenders and borrowers for the reasons discussed earlier. The market equilibrium hypothesis recognises that if markets function efficiently, supply and demand should be in equilibrium. However, a credit rationing problem exists, particularly in economic downturns, in that some prospective borrowers may not receive loans even if they are willing to pay higher interest rates. Proponents of the market equilibrium hypothesis argue that P2P lending platforms solve this credit rationing problem and bring the credit market towards equilibrium. 
Table 2.1 Size of the P2P lending market by region

\begin{tabular}{lccc}
\hline Region & Total market size & P2P consumer lending & P2P business lending \\
\hline & \multicolumn{3}{c}{2015} \\
The Americas & 28.70 & 18 & \\
Asia Pacific and China & 108.85 & 52.78 & 2.6 \\
Europe & 1.108 & 0.398 & 39.99 \\
Middle East and Africa & 0.242 & 0.010 & 0.23 \\
& & 2016 & 0.023 \\
The Americas & 35.2 & 21.1 & \\
Asia Pacific and China & 244.43 & 137.02 & 58.51 \\
Europe & 2.171 & 0.733 & 0.368 \\
Middle East and Africa & 0.36 & 0.033 & 0.031 \\
\hline
\end{tabular}

Notes All figures are reported in USD/billions

Sources Cambridge Centre for Alternative Finance (2017a, b, 2018a, b)

\subsection{Information Asymmetries and Peer to Peer Lending Platforms}

As discussed previously, except in a limited number of instances, for example, balance sheet business lending and balance sheet property lending, loans are granted by lenders and not the platform per se; the platform operator transfers the credit risk to the lenders. Addressing information asymmetries is a major theme of P2P lending platform research. As in the overwhelming majority of investment decisions, P2P lenders are at a disadvantage to the borrower with regard to the loan decision. The borrower has near-complete information while the lender has only what is presented by the P2P lending platform. As such, platform operators must design mechanisms into their platform and process to reduce these asymmetries while not demotivating either potential borrowers or lenders with unnecessary barriers to participate. Such mechanisms include provision point mechanisms (all or nothing), general platform rules, feedback systems, crowd due diligence, and safeguard funds. The provision of data and associated analysis and, in particular big data as online P2P lending marketplaces reach sufficient scale, is a critical component of differentiating P2P lending platforms but also reducing information asymmetries (Yan et al. 2015). A key mechanism in all $\mathrm{P} 2 \mathrm{P}$ lending platforms is some form of categorisation of a loan, typically proprietary, based on some platform assessment of the creditworthiness of the borrower represented by a credit grade (if not a credit score) 
representing the likelihood that the borrower will repay their debt. Such scores are derived from mandatory information disclosures from prospective borrowers such as credit history and personal data, but also supplemental voluntary information disclosures including more detailed biographical data, photographs, and in some cases, peer endorsements (Yan et al. 2015). Both conventional and non-standard information has been explored by researchers in terms of their contribution to key outcomes of the lending process, e.g. loan funding, final interest rate level, and default.

The importance of the credit grade as a signal is underlined by extant research which suggests, unsurprisingly, that higher credit grades are predictive of successful loan funding and lower risk of default (Greiner and Wang 2010; Emekter et al. 2015). A significant focus of research has been on so-called hard information which is easy to compare across borrowers and categories of borrowers. In addition to credit grade, debt-income ratio, bank account verification, and borrower debt level have been found to be significant for predicting funding probability and final interest rate (Greiner and Wang 2010; Serrano-Cinca et al. 2015). Despite this, it should be noted that Freedman and Jin (2008) suggest that exposure to credit grades rather than actual credit scores adversely effects loan decision making. In a similar vein, recent research suggests that credit grades may not represent accurate estimates of borrowers' creditworthiness, and that the accuracy of hard information for P2P lending decision-making is improved with further information disclosure (Serrano-Cinca et al. 2015; Tao et al. 2017; Zhu 2018).

Soft information in the context of P2P lending research typically refers to information about the borrower and their individual situation (Dorfleitner et al. 2016). Soft information is often viewed as a means to addressing information asymmetry and associated adverse selection in P2P lending platforms (Weiss et al. 2010; Gao et al. 2016; Prystav 2016). Iyer et al. (2009) suggest that screening through soft information, in this case, the number of friend endorsements and the loan purpose, is relatively more important when evaluating lower-quality borrowers. This is consistent with Prystav (2016) who found that borrowers with poorer relative credit ratings will be ignored if not for soft information. Gao et al. (2016) also identify that loan purpose is taken into account by lenders but they also note that they may be deceived by such information. Several studies have examined the narrative descriptions provided in loan listings. Research by Pötzsch and Böhme (2010) 
suggests that communicating soft information relating to the borrower's education, profession, and qualifications had a small but significant effect. Research by Herzenstein et al. (2011b) suggest that borrower claims about themselves (identities) in narratives that focus on trustworthiness or success increase the likelihood of loan funding but have less predictive loan performance than other identities, e.g. borrowers claiming economic hardship. Furthermore, borrowers who claim more identities in narratives both have increased likelihood of loan funding and a reduced final interest rate. Similarly, Michels (2012) suggests that voluntary information disclosures, over and above those required by the platform, even when unverified, results in an increase in bidding activity by prospective lenders and a reduction of interest rates. Dorfleitner et al. (2016) compared two European P2P lending platforms, and found that description text, and specifically spelling errors, text length, and the sentiment intensity of keywords, predicted funding probability on the less restrictive of the two platforms examined. Gao et al. (2016) show that the presence of well-established features that influence reader behaviours (readability, positive tones, and deception cues) in narrative texts of loan listings all meaningfully relate to loan repayment.

Many researchers have explored the extent to which lenders are rational or perceptual in their decision-making on $\mathrm{P} 2 \mathrm{P}$ lending platforms. Research on the Prosper.com platform by Herzenstein et al. (2008) suggests that prospective borrowers who provided a photo affected loan success negatively but found while demographic attributes, such as race and gender do affect likelihood of funding success, their influence was minor compared to other factors. Pope and Sydnor (2011) examining the same platform found evidence of racial disparities with loan listings featuring pictures with 'blacks' 25-35\% less likely to receive funding than pictures featuring 'whites'. Similarly, Ravina (2012) reports that after hard information is taken into account, more attractive prospective borrowers have a higher likelihood of loan funding and lower interest rates and that consistent with Pope and Sydnor (2011) identifies disparities between 'blacks' and 'whites'. Again using photographs of borrowers from Prosper.com, Duarte et al. (2012) found that borrowers who appear more trustworthy have higher probabilities of having their loans funded, have better credit scores and default less often. Age-based research would seem to be conclusive. Gonzalez and Loureiro (2014) found that loan success is sensitive to relative age and attractiveness. Furthermore, they found that (a) attractiveness had 
no effect where perceived age might signal competence, and (b) when the lender and borrower were of the same gender, attractiveness might negatively impact loan success. Similarly, research on Chinese borrower perceptions by Chen et al. (2016) suggests that borrowers perceived having a shared birthplace, location or occupation with lenders increased the 'ease of funding'. Burtch et al. (2014) note that location proximity and cultural differences in borrower and lender country of origin impact loan funding.

In many, but not all, P2P lending platforms operate auctions where the loan is only funded on a 'fund it all' basis, i.e. there must be sufficient bids to fund the loan amount requested loan in its entirety. This is sometimes referred to as the "rule of full funding" (Herzenstein et al. 2011a). As per other financial markets, where there is asymmetric (or imperfect) information, investors tend to herd (Bikhchandani and Sharma 2000). Bikhchandani and Sharma (2000, p. 280) define herding as follows:

an individual can be said to herd if she would have made an investment without knowing other investors' decisions, but does not make that investment when she finds that others have decided not to do so. Alternatively, she herds when knowledge that others are investing changes her decision from not investing to making the investment.

Bikchandani and Sharma (2000) differentiate between two types of herding-intentional and spurious. The former occurs when one set of investors copies another set of investors behaviour intentionally, i.e. the mimicry is post hoc; the latter occurs when investors behave similarly whether they are aware of the others investors' behaviour or not. Intentional herding may be rational or irrational. Rational herding is based on the observation of publicly visible investment choices or actions by one or more investors and therefore involves some form of observational learning and information cascades. In contrast, irrational whereas irrational herding is based on irrational beliefs or sentiment and is typified by momentum-investment strategies.

In the context of P2P lending, lenders may be particularly prone to herding due to the transparent nature of the platforms. Indeed this transparency and access to data also makes such platforms a fertile space for academic research. Berkovich (2011) analyses data from Prosper. com and his findings suggest that there is evidence of herding as per 
the model in Berkovich and Tayon (2009). Herzenstein et al. (2011a) examine strategic herding behaviour by lenders, again on Prosper.com. They identify that lenders are likely to herd in active auctions up until the loan is fully funded at which point, herding behaviour decreases. Interestingly, Herzenstein et al. (2011a) find that there is a positive association between strategic herding and loan repayment and suggest that such behaviour therefore benefits lenders individually and collectively. Zhang and Liu (2012) explore Prosper.com data also and conclude that the lenders engage in both rational and irrational herding based on the evidence of observational learning. Zhang and Liu's study is noteworthy as they observed counterintuitive herding effects, e.g. low credit scores amplified herding effects whereas favourable borrower characteristics seem to dampen herding effects. They also found that rational herding outperformed irrational herding in predicting loan performance.

Lee and Lee (2012) explore herding behaviour on a Korean P2P lending platform, Popfunding.com. Again, they find strong evidence of herding behaviour including a diminishing marginal effect of the observed herding behaviour as per Herzenstein et al. (2011a). More recently, Zhang and Chen (2017) investigate herding on a Chinese P2P lending platform. Again they find evidence of herding and in this case are able to identify both rational and irrational herding behaviour.

As a final related point, it is worth noting research relating to borrower groups within P2P lending platforms. In some P2P lending platforms, such as Prosper.com, it is common for borrowers to form groups comprising other borrowers, who may also in themselves act as lenders. Group leaders may set membership criteria that can require additional information from members over and above that required by the P2P lending platform and which may only be available to group leaders or the group. This group-specific private information is not available to all participants in the P2P lending platform. Given their status in groups, group leaders may wield considerable influence through endorsements or leading bidding. Research is inconclusive on groups (Lee and Lee 2012). Everett (2015) suggests that membership in a group with private information or enhanced monitoring is associated with lower default rates however not necessarily lower interest rates (Everett 2015). Everett (2015) suggests this private information disclosure, while solving an information asymmetry problem for some lenders, introduces a hold-up problem for some borrowers. Everett (2015) finds that consistent with 
extant literature, the interest rate often depends on the social relationship with the prospective borrower and the quality of the credit rating with more professional lenders seeking higher economic rents through higher interest rates. Notwithstanding this, Chen et al. (2016) find that group membership and the borrower's credibility and trust within that group yielded inconsistent results, however, the degree of group inclusiveness had a negative impact on, his/her funding and repayment performance.

Borrower groups may also play a role in herding. For example, group leader endorsements and bidding can initiate cascades leading to herding. Regarding the impact of group leader actions on loan funding, Kumar (2007) suggests group leader endorsement can increase the likelihood of loan funding success. However, the impact of group leader behaviour on interest rates is less conclusive. For example, while Berger and Gleisner (2010) suggest that active bidding by the group leader with others, and in itself, may result in lower interest rates, Freedman and Jin (2008) suggest that in certain instances group leader actions will increase the average interest rate.

\subsection{Conclusions And Future Directions FOR RESEARCH}

In this chapter, we provided an overview of online P2P lending platforms and discussed the extant literature on how information asymmetries are reduced through various platform mechanisms and the lenders themselves, including information disclosure, herding and relatedly in-platform groups. Peer-to-peer lending as a subset of the wider crowdfunding and FinTech domain is experiencing rapid adoption worldwide and is the dominant segment of most alternative finance markets. While there is a substantial literature base on information asymmetries and P2P lending, the increasingly global adoption of P2P lending, the proliferation of new platforms and marketplaces, and the evolution of new technologies provides a fertile ground for future research which we will discuss briefly.

Researchers have suggested that understanding the behaviour, and in particularly the 'inner life', of investors requires a greater appreciation of the both the socio-economic and technical context in which investment takes place (Hirsto 2011; Zwick and Schroeder 2011). For example, US data prior to 2008 operated under a different regulatory environment when the SEC required registration under the Securities Act of 1933 
resulting in changes to platform operation. Similarly, different countries operate under different levels of regulation and oversight. While there has been a small number of European studies and an increasing base of literature from China, the majority of early research has a US-focus. There is little truly comparative work examining the impact of local socio-economic forces, culture, language, and other aspects of national identity on borrower and lender behaviour on domestic and international $\mathrm{P} 2 \mathrm{P}$ lending platforms.

The number of $\mathrm{P} 2 \mathrm{P}$ lending platforms has increased dramatically since 2005. In China alone, media reports suggest over 2000 P2P lending platforms were active in the market in February 2018. Today, there are P2P lending platforms of every hue; they each have different features, functionalities, and affordances that impact the operation of the market. As with geo-cultural focus of early research, early P2P lending research focused on available datasets such as Prosper.com. Whether extant findings are generalisable across all platforms and take into account platform idiosyncrasies is worthy of further exploration.

The role and impact of information disclosure, hard and soft, has been the focus of much of the academic research to date. In this era of big data and API-fication, platforms are increasingly looking to integrate third-party data sources into P2P lending platforms. Yan et al. (2015) discuss the potentially transformational role such big data can have in reducing information asymmetry through reduced signalling and search costs. While highlighting the benefits of increased data volumes and variety, they warn that such volumes and velocity of data will only reduce information asymmetries where the quality of the data analysis and subsequent analysis is relatively high. Related technologies such as machine learning, deep learning and artificial intelligence similarly can contribute to loan decision-making and reducing information asymmetries but provide their own unique challenges and may result in unexpected consequences, not least diluting or removing the human element in P2P lending.

This chapter primarily focuses on information disclosure and herding as a means of reducing information asymmetries in P2P lending. Due to the large number of platforms operating today, there is greater heterogeneity in the structural mechanisms for reducing information asymmetries including provision point mechanisms, platform rules, contractual agreements, etc. The heterogeneity, scale, and global footprint of P2P lending 
and the strategic necessity of reducing information asymmetries to ensure the efficient operation of P2P lending platforms ensure a fervent space for scholarly inquiry and impact.

\section{REFERENCES}

Akerlof, G. A. (1970). The market for lemons: Quality uncertainty and the market mechanism. Quarterly Journal of Economics, 84(3), 488-500.

Berger, S. C., \& Gleisner, F. (2010). Emergence of financial intermediaries in electronic markets: The case of online P2P lending. BuR Business Research Journal, 2(1). Available at SSRN: https://ssrn.com/abstract=1568679.

Berger, A. N., \& Udell, G. F. (1998). The economics of small business finance: The roles of private equity and debt markets in the financial growth cycle. Journal of Banking \& Finance, 22(6), 613-673.

Berkovich, E. (2011). Search and herding effects in peer-to-peer lending: Evidence from prosper.com. Annals of Finance, 7(3), 389-405.

Berkovich, E., \& Tayon, R. (2009). Herding and crowding to efficiency. Phd. Dissertation-Essays on Search and Herding. University of Pennsylvania, Pennsylvania.

Bhide. (2003). The origin and evolution of new business. New York: Oxford University Press.

Bikhchandani, S., \& Sharma, S. (2000). Herd behavior in financial markets. IMF Staff Papers, 47(3), 279-310.

Burtch, G., Ghose, A., \& Wattal, S. (2014). Cultural differences and geography as determinants of online prosocial lending. Management Information Systems Quarterly, 38(3), 773-794.

Cambridge Centre for Alternative Finance. (2017a). Hitting Stride-The Americas Alternative Finance Industry Report.

Cambridge Centre for Alternative Finance. (2017b, September). Cultivating Growth-The 2nd Asia Pacific Region Alternative Finance Industry Report.

Cambridge Centre for Alternative Finance. (2018a). Expanding Horizons-The 3rd European Alternative Finance Industry Report.

Cambridge Centre for Alternative Finance. (2018b, June). The 2nd Annual Middle East and Africa Alternative Finance Industry Report.

Chen, X., Zhou, L., \& Wan, D. (2016). Group social capital and lending outcomes in the financial credit market: An empirical study of online peer-to-peer lending. Electronic Commerce Research and Applications, 15, 1-13.

Dorfleitner, G., Priberny, C., Schuster, S., Stoiber, J., Weber, M., de Castro, I., \& Kammler, J. (2016). Description text related soft information in peer-topeer lending-Evidence from two leading European platforms. Journal of Banking \& Finance, 64, 169-187. 
Duarte, J., Siegel, S., \& Young, L. (2012). Trust and credit: The role of appearance in peer-to-peer lending. The Review of Financial Studies, 25(8), 2455-2484.

Emekter, R., Tu, Y., Jirasakuldech, B., \& Lu, M. (2015). Evaluating credit risk and loan performance in online peer-to-peer (P2P) lending. Applied Economics, 47(1), 54-70.

Everett, C. R. (2015). Group membership, relationship banking and loan default risk: The case of online social lending. Banking and Finance Review, 7(2), 15-54.

Freedman, S., \& Jin, G. Z. (2008). Do social networks solve information problems for peer-to-peer lending? Evidence from Prosper.com (NET Institute Working Paper No. 08-43). Available at SSRN: https://ssrn.com/abstract=1304138.

Gao, Q., Lin, M., \& Sias, R. W. (2016). Words matter: The role of texts in online credit markets. Available at SSRN: https://ssrn.com/abstract $=2446114$.

Gonzalez, L., \& Loureiro, Y. K. (2014). When can a photo increase credit? The impact of lender and borrower profiles on online peer-to-peer loans. Journal of Behavioral and Experimental Finance, 2, 44-58.

Greiner, M. E., \& Wang, H. (2010). Building consumer-to-consumer trust in e-finance marketplaces: An empirical analysis. International Journal of Electronic Commerce, 15(2), 105-136.

Haas, P., Blohm, I., \& Leimeister, J. M. (2014). An empirical taxonomy of crowdfunding intermediaries. Proceedings of Thirty Fifth International Conference on Information Systems. Auckland: AIS.

Herzenstein, M., Dholakia, U. M., \& Andrews, R. L. (2011a). Strategic herding behavior in peer-to-peer loan auctions. Journal of Interactive Marketing, 25(1), 27-36.

Herzenstein, M., Sonenshein, S., \& Dholakia, U. M. (2011b). Tell me a good story and I may lend you money: The role of narratives in peer-to-peer lending decisions. Journal of Marketing Research, 48(SPL), S138-S149.

Herzenstein, M., Andrews, R. L., Dholakia, U. M., \& Lyandres, E. (2008). The democratization of personal consumer loans? Determinants of success in online peer-to-peer lending communities. Boston University School of Management Research Paper, 14(6).

Hirsto, H. (2011). Everyday discourses of stock market investing: Searching for investor power and responsibility. Consumption, Markets and Culture, 14(1), 57-77.

IOSCO. (2017, February). IOSCO Research Report on Financial Technologies (Fintech).

Iyer, R., Khwaja, A. I., Luttmer, E. F., \& Shue, K. (2009). Screening in new credit markets: Can individual lenders infer borrower creditworthiness in peerto-peer lending? (AFA 2011 Denver Meetings Paper). Available at SSRN: https://ssrn.com/abstract $=1570115$. 
Kotha, R., \& George, G. (2012). Friends, family, or fools: Entrepreneur experience and its implications for equity distribution and resource mobilization. Journal of Business Venturing, 27(5), 525-543.

Kumar, S. (2007). Bank of one: Empirical analysis of peer-to-peer financial marketplaces. AMCIS 2007 Proceedings (p. 305).

Lee, E., \& Lee, B. (2012). Herding behavior in online P2P lending: An empirical investigation. Electronic Commerce Research and Applications, 11(5), 495-503.

Maudos, J., \& De Guevara, J. F. (2004). Factors explaining the interest margin in the banking sectors of the European Union. Journal of Banking \& Finance, $28(9), 2259-2281$.

Meyer, T. (2007, July). Online P2P lending nibbles at banks' loan business. Deutsche Bank Research.

Michels, J. (2012). Do unverifiable disclosures matter? Evidence from peer-topeer lending. The Accounting Review, 87(4), 1385-1413.

Mills, K., \& McCarthy, B. (2014). The state of small business lending (Technical Report, Harvard Business School Working Paper).

Morse, A. (2015). Peer-to-peer crowdfunding: Information and the potential for disruption in consumer lending. Annual Review of Financial Economics, 7, $463-482$.

OECD. (2013). SME and entrepreneurship financing: The role of credit guarantee schemes and mutual guarantee societies in supporting finance for small and medium-sized enterprises. Paris: OECD Publishing. Available at: https://one. oecd.org/document/CFE/SME(2012)l/FINAL/en/pdf. Last accessed 18 July 2018.

OECD. (2017a). Enhancing the contributions of SMEs in a global and digitalised economy. Paris: OECD Publishing. Available at: https://www.oecd.org/ mcm/documents/C-MIN-2017-8-EN.pdf. Last accessed 18 July 2018.

OECD. (2017b). Financing SMEs and entrepreneurs 2017. An OECD scoreboard. Paris: OECD Publishing. Available at: https://www.oecd.org/cfe/smes/ Financing\%20SMEs\%20and\%20Entrepreneurs\%202017_Highlights.pdf. Last accessed 18 July 2018.

Pope, D. G., \& Sydnor, J. R. (2011). What's in a picture? Evidence of discrimination from Prosper. com. Journal of Human Resources, 46(1), 53-92.

Pötzsch, S., \& Böhme, R. (2010). The role of soft information in trust building: Evidence from online social lending. In International Conference on Trust and Trustworthy Computing (pp. 381-395). Berlin and Heidelberg: Springer.

Prystav, F. (2016). Personal information in peer-to-peer loan applications: Is less more? Journal of Behavioral and Experimental Finance, 9, 6-19.

Ravina, E. (2012). Love \& loans: The effect of beauty and personal characteristics in credit markets (June 15, 2018). Available at SSRN: https://ssrn.com/ abstract $=1107307$ or https://doi.org/10.2139/ssrn.1107307. 
Robb, A. M., \& Robinson, D. T. (2014). The capital structure decisions of new firms. Review of Financial Studies, 27(1), 153-179.

Serrano-Cinca, C., Gutierrez-Nieto, B., \& López-Palacios, L. (2015). Determinants of default in P2P lending. PLoS One, 10(10), e0139427.

Sviokla, J. (2009). Breakthrough ideas: Forget Citibank-Borrow from Bob. Harvard Business Review, 87(2), 29-40.

Tao, Q., Dong, Y., \& Lin, Z. (2017). Who can get money? Evidence from the Chinese peer-to-peer lending platform. Information Systems Frontiers, 19(3), 425-441.

Wang, H., Greiner, M., \& Aronson, J. E. (2009). People-to-people lending: The emerging e-commerce transformation of a financial market. Value creation in E-business management (pp. 182-195). Berlin and Heidelberg: Springer.

Weiss, G. N. F., Pelger, K., \& Horsch, A. (2010). Mitigating adverse selection in P2P Lending-Empirical evidence from prosper.com (July 29, 2010). Available at SSRN: https://ssrn.com/abstract=1650774 or https://doi. org/10.2139/ssrn.1650774.

Yan, J., Yu, W., \& Zhao, J. L. (2015). How signaling and search costs affect information asymmetry in P2P lending: The economics of big data. Financial Innovation, $1(1), 19$.

Yum, H., Lee, B., \& Chae, M. (2012). From the wisdom of crowds to my own judgment in microfinance through online peer-to-peer lending platforms. Electronic Commerce Research and Applications, 11(5), 469-483.

Zhang, K., \& Chen, X. (2017). Herding in a P2P lending market: Rational inference OR irrational trust? Electronic Commerce Research and Applications, 23, 45-53.

Zhang, J., \& Liu, P. (2012). Rational herding in microloan markets. Management Science, 58(5), 892-912.

Zhu, Z. (2018). Safety promise, moral hazard and financial supervision: Evidence from peer-to-peer lending. Finance Research Letters.

Zwick, D., \& Schroeder, J. (2011). Stock trading in the digital age: Speed, agency, and the entrepreneurial consume. In R. W. Belk \& R. Llamas (Eds.), The Routledge companion to digital consumption. Abingdon, UK: Routledge. 
Open Access This chapter is licensed under the terms of the Creative Commons Attribution-NonCommercial-NoDerivatives 4.0 International License (http://creativecommons.org/licenses/by-nc-nd/4.0/), which permits any noncommercial use, sharing, distribution and reproduction in any medium or format, as long as you give appropriate credit to the original author(s) and the source, provide a link to the Creative Commons license and indicate if you modified the licensed material. You do not have permission under this license to share adapted material derived from this chapter or parts of it.

The images or other third party material in this chapter are included in the chapter's Creative Commons license, unless indicated otherwise in a credit line to the material. If material is not included in the chapter's Creative Commons license and your intended use is not permitted by statutory regulation or exceeds the permitted use, you will need to obtain permission directly from the copyright holder.

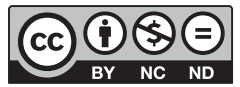

